\title{
PRODUKSI DAN LAJU DEKOMPOSISI SERASAH MANGROVE (Rhizophora sp.) DI DESA DURIAN DAN DESA BATU MENYAN KECAMATAN PADANG CERMIN KABUPATEN PESAWARAN
}

\section{(PRODUCTION AND DECOMPOSITION RATE OF MANGROVE (Rhizophora sp.) LITTER LEAF IN DURIAN VILLAGE AND BATU MENYAN VILLAGE PADANG CERMIN SUBDISTRICT PESAWARAN REGENCY)}

\author{
Feri Andrianto, Afif Bintoro dan Slamet Budi Yuwono \\ Jurusan Kehutanan, Fakultas Pertanian, Universitas Lampung \\ Jln. Prof. Dr. Soemantri Brojonegoro No.1 Gedong Meneng, Bandar Lampung \\ Email: feri_sylva09@yahoo.co.id, Nomor telepon: 089631612977
}

\begin{abstract}
ABSTRAK
Serasah mangrove merupakan penyuplai bahan organik terhadap kesuburan ekosistem mangrove, sehingga mampu menunjang kehidupan makhluk hidup di dalamnya. Kawasan hutan mangrove merupakan tempat asuhan (nursery ground), tempat mencari makan (feeding ground), dan daerah pemijahan (spawning ground) bagi berbagai jenis ikan, udang dan biota laut lainnya serta sebagai penghasil sejumlah besar detritus bagi plankton yang merupakan sumber makanan utama biota laut. Tujuan penelitian ini adalah untuk mengetahui produksi dan laju dekomposisi serasah mangrove di ekosistem mangrove di Desa Durian dan Desa Batu Menyan Kecamatan Padang Cermin, Kabupaten Pesawaran. Analisis data untuk produksi serasah yaitu dengan menghitung rata-rata bobot kering serasah yang dihasilkan dan untuk laju dekomposisi menggunakan fungsi eksponensial pangkat atau persentase penguraian mutlak serasah per hari. Penelitian dilakukan di dua tempat (stasiun) yang dibedakan berdasarkan karakteristik substratnya. Penelitian dilakukan dari Oktober sampai dengan Desember 2013. Produktivitas serasah hutan mangrove di kedua stasiun sebesar 0,56 $\mathrm{g} / \mathrm{m}^{2} /$ hari, dimana organ daun memberikan kontribusi yang paling banyak (66\%), ranting dan cabang (14\%), bunga dan buah (20\%). Laju dekomposisi serasah daun mangrove memperlihatkan bahwa stasiun 2 (kedua) mengalami laju dekomposisi lebih cepat $(0,20 \mathrm{~g} / \mathrm{hr})$ dibandingkan stasiun 1 (kesatu) $(0,19 \mathrm{~g} / \mathrm{hr})$.
\end{abstract}

Kata kunci : Laju dekomposisi, mangrove, produksi, serasah

\section{ABSTRACT}

Mangrove litter leaf represent the organic substance supplier towards fertility of mangrove ecosystem, that able to support the mortal life within. The area of forest of mangrove represent the nursery ground, feeding ground, and area of spawning ground for various fish type, prawn and other biota sea and also as producer of amount of detritus for plankton as main foods source of the sea. The objectives of this research were to know production and decomposition rate of mangrove litter leaf in the mangrove ecosystem of Durian Village and Batu Menyan Village, Padang Cermin subdistrict, Pesawaran regency. Data was analysed by calculating the dry weight mean of litter leaf production and to counting decomposition rate was using the exponential rank function or from absolute decomposition percentage of litter leaf per day. This research was conducted in two place (station) based on the difference of substrate characteristic. The research conducted from October to December 2013. The productivity of mangrove's litter leaf in both places is $0,56 \mathrm{~g} / \mathrm{m}^{2} /$ day, where the leaf organ gave the higgest contribution, (66\%), stick and branch (14\%), flower and fruit 
(20\%). Decomposition rate of mangrove litter leaf showed that at the second station $(0,20 \mathrm{~g}$ / hr) was faster than the first station $(0,19 \mathrm{~g} / \mathrm{hr})$.

Keywords : Decomposition rate, litter leaf litter leaf, mangrove, production

\section{PENDAHULUAN}

Serasah vegetasi mangrove yang telah terurai melalui proses dekomposisi, sebagian akan diserap oleh mangrove itu sendiri dan sebagian lainnya menjadi tambahan masukan bahan organik bagi ekosistem mangrove di sekitarnya. Manfaat akumulasi bahan organik hasil dekomposisi serasah hutan mangrove antara lain memperkaya hara pada ekosistem mangrove, sebagai daerah asuhan dan pembesaran (nursery ground), daerah pemijahan (spawning ground), dan perlindungan bagi aneka biota perairan (Wibisana, 2004). Selain itu, akumulasi bahan organik juga mampu mereduksi potensi subsidensi permukaan lahan hutan mangrove. Bahan organik yang tersedia di kawasan tersebut berasal dari bagian-bagian pohon, terutama yang berupa daun.

Akumulasi bahan organik ditentukan oleh dua faktor yaitu faktor produksi dan faktor dekomposisi. Secara umum produksi bahan organik ditentukan oleh jenis dan kerapatan tegakan hutan mangrove, dimana semakin rapat tegakan produksi bahan organik juga meningkat, sedangkan dekomposisi juga ditentukan oleh jenis bahan organik maupun oleh faktor dekomposernya.

Dekomposisi merupakan proses penghancuran/penguraian bahan organik mati yang dilakukan oleh agen biologi maupun fisika menjadi bahan-bahan mineral dan humus koloidal organik. Oleh karena itu, dekomposisi bahan organik juga sering disebut proses mineralisasi. Proses ini merupakan proses mikroba (dekomposer) dalam memperoleh energi bagi perkembangbiakannya. Adapun faktor-faktor yang mempengaruhi proses dekomposisi bahan organik dari sisi dekomposernya adalah suhu, kelembaban, salinitas, dan pH. Proses ini sangat besar peranannya dalam siklus energi dan rantai makanan pada ekosistem mangrove.

Penelitian tentang dinamika serasah mangrove berupa produksi dan laju dekomposisi di kawasan hutan mangrove Kecamatan Padang Cermin mempunyai arti penting karena serasah merupakan sumbangan terbesar dari ekosistem mangrove terhadap kesuburan esturia, sehingga peran hutan mangrove sebagai pendukung dan penyedia jasa-jasa bagi kelangsungan hidup manusia dapat terjaga. Penelitian ini bertujuan untuk mengetahui produksi dan laju dekomposisi serasah mangrove di ekosistem mangrove Desa Durian dan Desa Batu Menyan Kecamatan Padang Cermin Kabupaten Pesawaran. Akumulasi netto bahan organik yang penting dalam peranannya sebagai penunjang kehidupan makhluk hidup di dalam ekosisitem mangrove belum banyak diketahui, sehingga perlu dilakukan penelitian.

\section{METODE PENELITIAN}

\section{Waktu dan Tempat Penelitian}

Penelitian ini dilakukan pada Oktober sampai dengan Desember 2013 di Desa Durian dan Desa Batu Menyan Kecamatan Padang Cermin Kabupaten Pesawaran. 


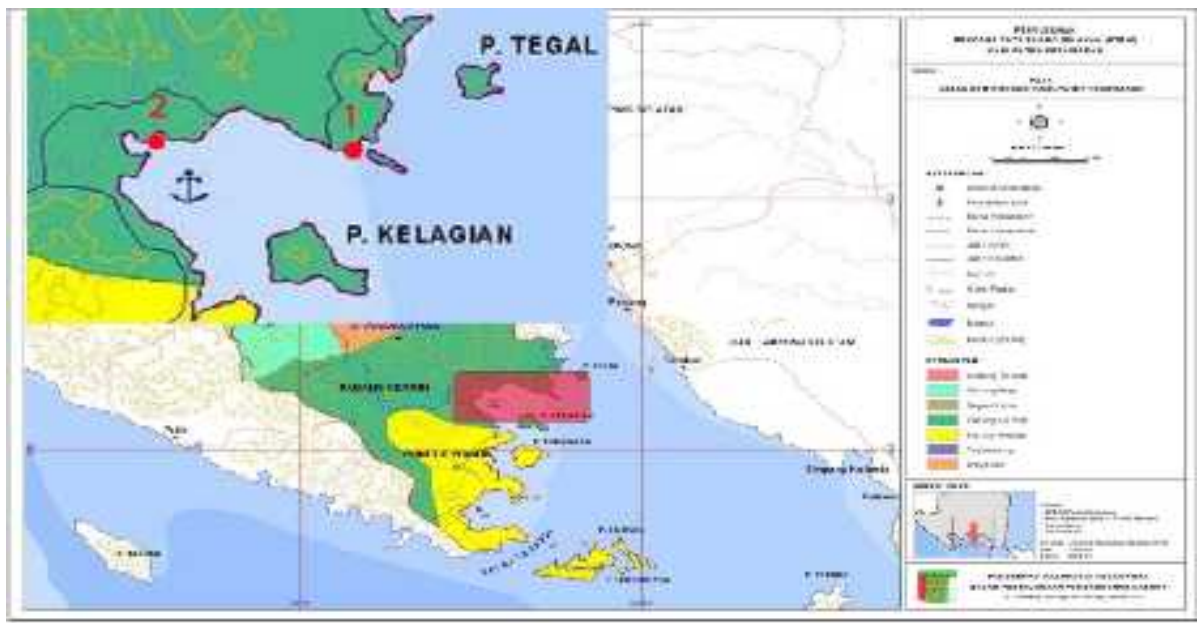

Gambar 1. Peta lokasi penelitian.

\begin{abstract}
Alat dan Bahan
Alat yang digunakan dalam penelitian ini terdiri dari : kantong serasah/litter-bag (wadah serasah daun untuk dekomposisi yang terbuat dari nilon) berukuran $30 \mathrm{~cm} \mathrm{x} 30 \mathrm{~cm}$ dengan mata jaring berukuran $1 \mathrm{~mm}$ yang dilengkapi tali pengerut pada bagian salah satu ujungnya dan diikatkan pada akar atau batang mangrove, jaring/litter-trap berupa jaring penampung berukutan $1 \mathrm{~m} \times 1 \mathrm{~m}$, timbangan, oven, kantong plastik, tali rafia, kamera, kantong kertas HVS, alat tulis, termometer, refraktometer, pHmeter, patok dan kertas label. Bahan yang digunakan pada penelitian ini adalah serasah mangrove Rhizophora sp. Sampel air masing-masing stasiun.
\end{abstract}

\title{
Prosedur Penelitian
}

\section{Penentuan Stasiun Penelitian}

Lokasi penelitian dibagi atas dua stasiun pengamatan yang dibedakan karakteristiknya berdasarkan interaksinya, tiap-tiap stasiun terdiri dari 3 sub stasiun pengamatan. Stasiun 1 (kesatu) di daerah pasang surut, yaitu daerah dimana mangrove selalu terkena pasang surut air laut secara langsung. Stasiun 2 (kedua) di daerah air payau, yaitu daerah yang tidak terkena pasang surut air laut secara langsung.

\section{Pengambilan Sampel}

\section{a) Pengambilan Sampel Pengukuran Produksi Serasah (Litter-fall)}

Metode umum yang digunakan untuk menangkap guguran serasah di hutan mangrove dalam waktu tertentu (liner-fall) adalah dengan litter-trap (jaring penangkap serasah) (Brown, 1984). Litter-trap berupa jaring penampung berukuran $1 \mathrm{~m} \mathrm{x} 1 \mathrm{~m}$, yang terbuat dari nylon dengan ukuran mata jaring sekitar $1 \mathrm{~mm}$ dan bagian bawahnya diberi pemberat. Littertrap diletakkan di antara vegetasi mangrove terdekat dengan ketinggian di atas garis pasang tertinggi. Pada setiap stasiun dipasang 3 jaring penampung. Pengukuran produktivitas serasah dilaksanakan bersamaan dengan mulai dilakukannya penelitian laju dekomposisi selama 2 bulan dengan selang waktu pengambilan selama 20 hari.

Serasah yang sudah dikumpulkan, dipisahkan berdasarkan setiap bagiannya antara daun, ranting, dan bunga/buah. Serasah tersebut ditimbang beratnya lalu dimasukkan ke dalam kantong plastik dan diberi label, untuk selanjutnya dibawa ke laboratorium. Pengukuran berat kering serasah dilaksanakan di laboratorium dengan cara mengeringkan sampel ke dalam oven pada suhu $80^{\circ} \mathrm{C}$ selama $2 \times 24$ jam atau hingga beratnya konstan. 


\section{b) Pengukuran Laju Dekomposisi Serasah}

Pengukuran laju dekomposisi serasah dilakukan secara eksperimental di lapangan, yakni dengan meletakkan serasah daun yang telah dikeringkan sebanyak $10 \mathrm{~g}$ ke dalam kantong serasah (liner-bag) berukuran $30 \mathrm{~cm} \times 30 \mathrm{~cm}$ yang terbuat dari nilon dengan mata jaring $1 \mathrm{~mm}$ (Pribadi, 1998; Ashton et al, 1999). Di setiap stasiun pengamatan dipasang 3 kantong serasah (liner bag) dengan tiga kali pengulangan. Litter-bag diikatkan pada akar atau batang mangrove agar tidak terbawa air pasang. Litter-bag diambil dari masing-masing lokasi pengamatan pada 0, 20, 40 dan 60 hari. Setiap selesai waktu pengambilan, serasah dari litter- bag dikeluarkan dan ditiriskan, untuk selanjutnya diukur beratnya. Di laboratorium, serasah tersebut selanjutnya dikeringkan pada suhu $105^{\circ} \mathrm{C}$ hingga beratnya konstan (Ashton et al, 1999), lalu diukur berat keringnya. Laju dekomposisi serasah dihitung dari penyusutan bobot serasah yang didekomposisikan dalam satu satuan waktu dan kandungan unsur hara $\mathrm{C}$ dan $\mathrm{N}$.

\section{c) Pengambilan Sampel Air}

Sampel air diambil dengan menggunakan water sampler lalu dimasukkan ke dalam botol (sebelumnya telah dicuci dengan larutan asam lemah). Sampel selanjutnya dimasukkan ke dalam kotak penyimpanan untuk menghindari terjadinya kontaminasi. Sampel air selanjutnya dibawa ke Laboratorium Penguji Kesehatan Ikan dan Lingkungan Balai Besar Pengembangan Budidaya Laut Lampung untuk dianalisis Total Padatan Tersuspensi (TSS), salinitas, dan $\mathrm{pH}$. Pengukuran parameter lingkungan lainnya seperti suhu dilakukan langsung di lapangan.

\section{Analisis Data}

\section{a) Produksi Serasah}

Data yang diperoleh dari hasil pengamatan pada masing-masing stasiun diolah dalam bentuk tabulasi. Data yang dianalisis adalah rata-rata serasah yang dihasilkan $\mathrm{g} / \mathrm{m}^{2} / 60$ hari.

\section{b) Laju Dekomposisi Serasah}

Laju dekomposisi serasah dihitung dengan menggunakan persamaan :

Keterangan:

$$
\mathrm{R}=\frac{\mathrm{Wo}-\mathrm{Wt}}{\mathrm{T}}
$$

$R \quad=$ Laju dekomposisi (g/hari)

$T \quad=$ Waktu pengamatan (hari)

$W o$ = Berat kering sampel serasah awal $(\mathrm{g})$

$W t \quad=$ Berat kering sampel serasah setelah waktu pengamatan ke-t $(\mathrm{g})$

Persentase penguraian serasah diperoleh dengan menggunakan rumus (Boonruang, 1984) :

Keterangan :

$$
\mathrm{Y}=\frac{W o-W t}{\mathrm{Wo}} x 100 \%
$$

$Y=$ Persentase serasah daun yang mengalami dekomposisi

$W o=$ Berat kering serasah awal $(\mathrm{g})$

$W t=$ Berat kering serasah setelah waktu pengamatan ke-t $(\mathrm{g})$

Pendugaan nilai konstanta laju dekomposisi serasah diperoleh dengan menggunakan rumus (Ashton et al, 1999): 
Keterangan :

$$
\begin{gathered}
X t=X o \cdot e^{-k t} \\
\ln (X t / X o)=-k t
\end{gathered}
$$

$X t=$ berat kering serasah setelah waktu pengamatan ke $-\mathrm{t}(\mathrm{g})$

$X o=$ berat kering serasah awal $(\mathrm{g})$

$e=$ bilangan logaritma natural $(2,72)$

$k=$ konstanta laju dekomposisi serasah

$t=$ waktu pengamatan (hari)

\section{c) Analisis Karbon dan Nitrogen}

Analisis kandungan karbon dan nitrogen pada serasah mangrove dilakukan secara deskriptif. Selanjutnya akan ditampilkan dalam bentuk grafik/histogram yang menggambarkan hubungan antara kadar carbon dan kadar nitrogen yang terdapat di setiap stasiun pengamatan.

\section{Produksi Serasah}

\section{HASIL DAN PEMBAHASAN}

Produksi serasah rata-rata pada stasiun 1 (kesatu) terdiri dari daun $10,53 \mathrm{~g} / \mathrm{m}^{2} / 60$ hari (67\%), ranting dan cabang $1,48 \mathrm{~g} / \mathrm{m}^{2} / 60$ hari (9\%), dan bunga dan buah $3,73 \mathrm{~g} / \mathrm{m}^{2} / 60$ hari (24\%). Sedangkan produksi serasah rata-rata pada stasiun 2 (kedua) terdiri dari daun 22,94 $\mathrm{g} / \mathrm{m}^{2} / 60$ hari $(66 \%)$, ranting dan cabang $5,30 \mathrm{~g} / \mathrm{m}^{2} / 60$ hari $(15 \%)$, dan bunga dan buah 6,56 $\mathrm{g} / \mathrm{m}^{2} / 60$ hari $(19 \%)$. Secara lengkap produksi serasah rata-rata pada stasiun 1 (kesatu) dan stasiun 2 (kedua) disajikan dalam Tabel 1 dan Gambar 2.

Tabel 1. Produksi serasah stasiun 1 (kesatu) dan stasiun 2 (kedua).

\begin{tabular}{cllll}
\hline \multicolumn{5}{c}{ Produktivitas serasah $\left(\mathbf{g} / \mathbf{m}^{\mathbf{2}} / \mathbf{6 0 h a r i}\right)$} \\
\hline \multirow{2}{*}{ Stasiun } & sub stasiun & Daun & Ranting \& cabang & Bunga \& buah \\
\hline \multirow{2}{*}{1} & 1.1 & 11,43 & 1,35 & 4,63 \\
& 1.2 & 10,33 & - & 5,13 \\
& 1.3 & 9,83 & 1,60 & 1,43 \\
\hline Total & & 31,60 & 2,95 & 11,20 \\
\hline Rata-rata & & 10,53 & 1,48 & 3,73 \\
\hline \multirow{2}{*}{2} & 2.1 & 22,07 & 8,93 & 10,53 \\
& 2.2 & 23,27 & 3,00 & 4,37 \\
\hline Total & 2.3 & 23,50 & 3,97 & 4,77 \\
\hline Rata-rata & & 68,83 & 15,90 & 19,67 \\
\hline Sumber : Data & 22,94 & 5,30 & 6,56 \\
\hline
\end{tabular}

Sumber : Data primer (2013)

Produksi total yang terbesar adalah serasah daun yang menyumbang $33,02 \mathrm{~g} / \mathrm{m}^{2}$ dari total keseluruhan serasah yang tertampung dalam jaring serasah. Hal ini terjadi karena serasah daun mempunyai periode biologi yang lebih singkat (cepat gugur) dibandingkan komponen serasah lainnya (ranting, bunga dan buah). Selain itu, daun juga cenderung lebih mudah digugurkan oleh hembusan angin dan terpaan hujan. 

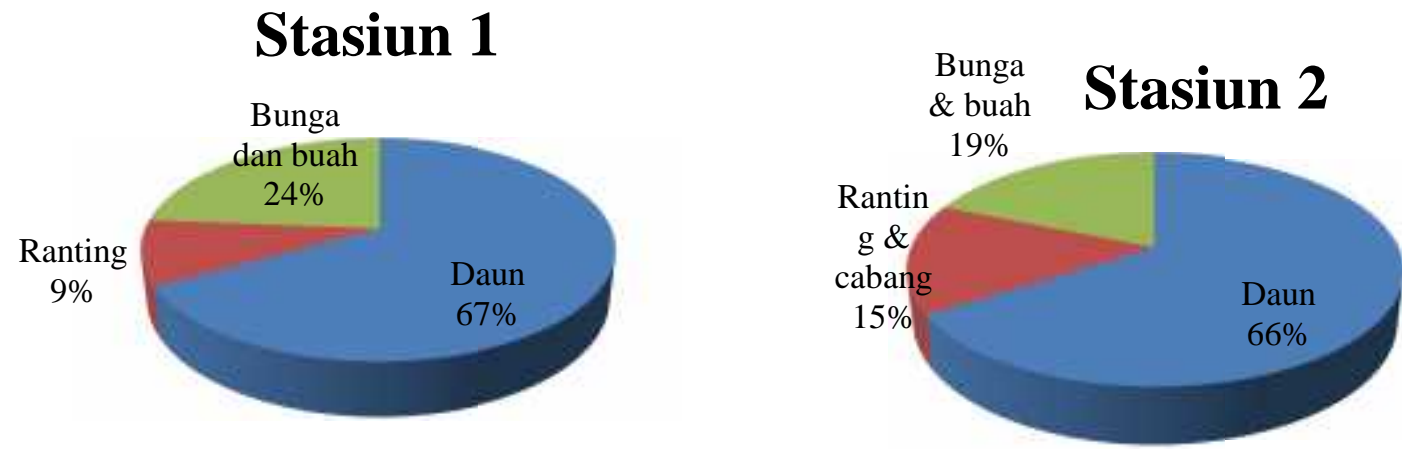

Gambar 2. Proporsi komponen serasah tiap stasiun.

Stasiun 2 (kedua) menghasilkan produksi serasah sebesar $34,8 \mathrm{~g} / \mathrm{m}^{2} / 60$ hari, dan stasiun 1 (kesatu) menghasilkan serasah sebanyak $15,74 \mathrm{~g} / \mathrm{m}^{2} / 60$ hari. Keadaan ini menunjukkan bahwa kondisi fisik lingkungan tempat tumbuh masing-masing stasiun mempengaruhi terjadinya produktivitas serasah mangrove, selain itu jenis mangrove juga berpengaruh terhadap produktivitas mangrove itu sendiri. Jenis mangrove pada stasiun 1 (kesatu) didominasi oleh Rhizophora stylosa sedangkan pada stasiun 2 (kedua) didominasi oleh jenis Rhizophora mucronata. Bentuk dan ukuran daun jenis Rhizophora mucronata yang lebih besar daripada Rhizophora stylosa hal ini menyebabkan daun mudah gugur saat diterpa angin. Hal ini diperkuat dengan penelitian yang dilakukan Zamroni (2008), dalam penelitiannya produksi serasah mangrove jenis Rhizophora mucronata $(54,7 \%)$ sedangkan jenis Rhizophora stylosa hanya $(9,3 \%)$.

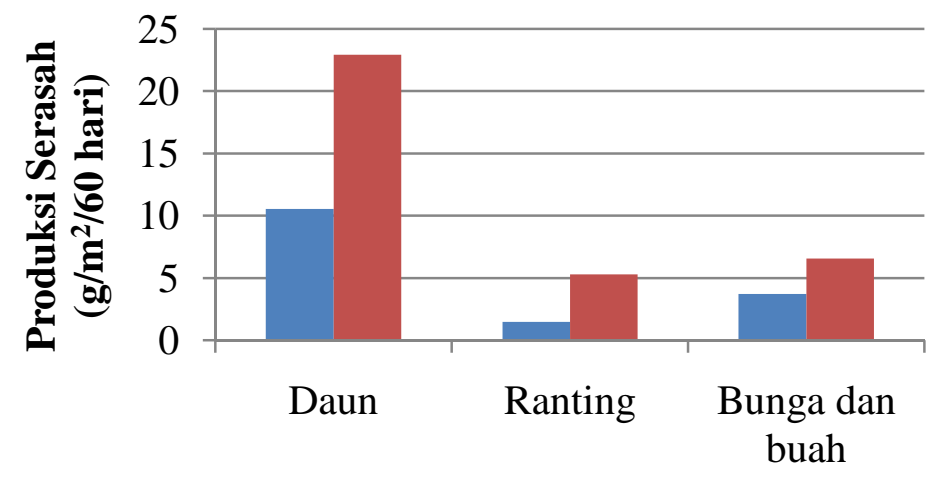

- Stasiun $1 \quad$ Stasiun 2

Gambar 3. Produksi serasah tiap stasiun.

Kondisi rata-rata kerapatan tegakan mangrove pada stasiun 1 (kesatu) adalah 3 individu $/ 10 \mathrm{~m}^{2}$ atau 101 individu/ha, kondisi ini jauh berbeda bila dibandingkan dengan stasiun 2 (kedua) dengan rata-rata kerapatan 10 individu/10 $\mathrm{m}^{2}$ atau 323 individu/ha. Hal ini sesuai dengan penelitian yang dilakukan Sopana (2011), yang menyatakan bahwa kerapatan pohon mangrove mempengaruhi produksi serasah, semakin tinggi kerapatan pohon, maka semakin tinggi pula produksi serasahnya. Begitu pula sebaliknya semakin rendah kerapatan pohon mangrove maka semakin rendah produksi serasahnya. 
Tabel 2. Produktivitas serasah mangrove di beberapa lokasi penelitian.

\begin{tabular}{|c|c|c|c|c|}
\hline No & Sumber & Lokasi Penelitian & Jenis mangrove & $\begin{array}{l}\text { Produksi serasah } \\
\left(\mathrm{g} / \mathrm{m}^{2} / \mathrm{hari}\right)\end{array}$ \\
\hline 1 & $\begin{array}{l}\text { Asthon } \text { et } \\
\text { al, } 1999\end{array}$ & $\begin{array}{l}\text { Peninsular, } \\
\text { Malaysia }\end{array}$ & $\begin{array}{l}R . \text { mucronata dan } R \text {. } \\
\text { apiculata }\end{array}$ & 2,79 \\
\hline 2 & $\begin{array}{l}\text { Pribadi, } \\
1998\end{array}$ & $\begin{array}{l}\text { Teluk Bintuni, } \\
\text { Papua }\end{array}$ & $\begin{array}{l}\text { Rhizophora spp dan } \\
\text { Bruguera spp }\end{array}$ & 3,04 \\
\hline 3 & $\begin{array}{l}\text { Handayani, } \\
2004\end{array}$ & $\begin{array}{l}\text { Kepulauan seribu, } \\
\text { Jakarta }\end{array}$ & Rhizopohora mucronata & 4,21 \\
\hline 4 & $\begin{array}{l}\text { Katimura, } \\
1997\end{array}$ & Teluk Benoa, Bali & Rhizophora apiculata & 3,81 \\
\hline
\end{tabular}

Sumber : Lestarina (2011)

Apabila dibandingkan dengan produktivitas mangrove pada berbagai lokasi (Tabel 2), lokasi penelitian ini menghasilkan produksi rata-rata serasah sebesar $0,56 \mathrm{~g} / \mathrm{m}^{2} / \mathrm{hari}$, kondisi tersebut memberikan produktivitas yang cukup rendah bila dibandingkan dengan beberapa lokasi mangrove lainnya. Hal ini dikarenakan kondisi hutan mangrove di lokasi penelitian mempunyai kerapatan yang rendah pula, stasiun 1 (kesatu) 101 individu/ha dan stasiun 2 (kedua) 323 individu/ha.

\section{Laju Dekomposisi}

Proses dekomposisi serasah mangrove selama 60 hari menunjukkan bahwa belum ada serasah terdekomposisi secara sempurna (100\%). Bobot kering serasah daun mangrove disajikan dalam Tabel 3.

Tabel 3. Penyusutan bobot kering serasah daun mangrove.

\begin{tabular}{|c|c|c|c|c|c|}
\hline \multicolumn{6}{|c|}{ Bobot kering serasah daun mangrove (g) } \\
\hline Stasiun & Sub Stasiun & Berat Awal & Hari ke-20 & Hari ke-40 & Hari ke-60 \\
\hline \multirow{3}{*}{1} & 1.1 & 10,00 & 5,50 & 2,90 & 2,80 \\
\hline & 1.2 & 10,00 & 5,00 & 2,90 & 1,40 \\
\hline & 1.3 & 10,00 & 5,10 & 3,20 & 1,20 \\
\hline \multirow[t]{2}{*}{ Rata-rata } & & 10,00 & 5,20 & 3,00 & 1,80 \\
\hline & 2.1 & 10,00 & 4,40 & 1,80 & 0,60 \\
\hline \multirow[t]{2}{*}{2} & 2.2 & 10,00 & 4,10 & 2,50 & 0,80 \\
\hline & 2.3 & 10,00 & 4,60 & 3,00 & 1,20 \\
\hline Rata-rata & & 10,00 & 4,37 & 2,43 & 0,87 \\
\hline
\end{tabular}

Sumber : Data primer (2013)

Rata-rata sisa bobot kering daun mangrove paling banyak terdapat di stasiun 1 (kesatu) yaitu 1,80 gram, sedangkan pada stasiun 2 (kedua) sisa bobot kering daun mangrove yaitu 0,87 gram. Sisa bobot kering daun mangrove pada stasiun 2 (kedua) lebih sedikit dibandingkan dengan stasiun 1 (kesatu). Hal ini menjelaskan bahwa proses dekomposisi pada stasiun 1 (kesatu) lebih rendah dibandingkan dengan stasiun 2 (kedua). Proses dekomposisi ini sangat dipengaruhi oleh kondisi lingkungan dan substrat. Faktor yang menyebabkan dekomposisi di stasiun 2 (kedua) lebih cepat dibandingkan dengan stasiun 1 
(kesatu) adalah karakteristik substrat dan genangan air. Pada stasiun 2 (kedua) umumnya kondisi substratnya berlumpur, sedangkan pada stasiun 1 (kesatu) lebih didomonasi oleh pasir. Hal ini sejalan dengan hasil penelitian yang dilakukan Syamsurisal (2011), yang menyatakan bahwa kelimpahan mikroba (dekomposer) banyak terdapat di daerah muara sungai yang bersubstrat lumpur yang mengandung banyak bahan organik. Selain itu, penempatan kantong serasah di stasiun 2 (kedua) berada dalam kolom perairan karena habitatnya selalu tergenang air, sehingga pembusukan lebih cepat terjadi. Sedangkan pada stasiun 1 (kesatu), dimana daerah yang menjadi tempat serasah lebih banyak yang tidak tergenang pada saat surut. Keberadaan nutrient juga dipengaruhi oleh komposisi sedimen, sedimen yang banyak mengandung lumpur umumnya kaya bahan organik dibandingkan sedimen berpasir (English, 1994 dikutip oleh Lekatompessy dan Tutuhatunewa, 2010).

Tabel 4. Rata-rata laju dekomposisi serasah mangrove stasiun 1 (kesatu) dan 2 (kedua) secara berkala

\begin{tabular}{llll}
\hline \multirow{2}{*}{ Stasiun } & \multicolumn{2}{l}{ Rata-rata laju dekomposisi serasah mangrove $(\mathrm{g} / \mathrm{hari})$} \\
\cline { 2 - 4 } & $\mathbf{2 0}$ hari & $\mathbf{4 0}$ hari & $\mathbf{6 0}$ hari \\
\hline Stasiun 1 & 0,24 & 0,18 & 0,14 \\
Stasiun 2 & 0,26 & 0,19 & 0,15 \\
\hline
\end{tabular}

Sumber : Data primer (2013)

Tabel 4 menunjukkan rata-rata laju dekomposisi serasah daun mangrove pada stasiun 1 (kesatu) dan 2 (kedua). Laju dekomposisi berlangsung cepat pada 20 hari pertama pada kedua stasiun. Pada stasiun 1 (kesatu) yaitu $0,24 \mathrm{~g} / \mathrm{hr}$ sedangkan pada 20 hari berikutnya sebesar $0,18 \mathrm{~g} / \mathrm{hr}$ dan pada 20 hari terakhir sebesar $0,14 \mathrm{~g} / \mathrm{hr}$. Rata-rata laju dekomposisi serasah daun mangrove pada stasiun 2 (kedua) yaitu $0,26 \mathrm{~g} / \mathrm{hr}$ sedangkan pada 20 hari berikutnya sebesar $0,19 \mathrm{~g} / \mathrm{hr}$ dan pada 20 hari terakhir sebesar $0,15 \mathrm{~g} / \mathrm{hr}$.

Proses dekomposisi dimulai dari proses penghancuran/fragmentasi atau pemecahan struktur fisik terjadi ketika serasah gugur dan terperangkap di ekosistem mangrove. Bahanbahan organik yang terdapat di dalam serasah akan dikonsumsi oleh dekomposer. Laju dekomposisi sersah daun terjadi penurunan yang sangat signifikan pada hari ke 40 yaitu dengan kisaran 0,06 -- 0,07. Sedangkan pada hari ke-40 sampai hari ke-60 relatif konstan, dengan kisaran 0,14 -- 0,19 g/hari. Hal ini disebabkan oleh menurunnya bahan-bahan organik dan kandungan nitrogen yang terdapat dalam sisa daun. Rata- rata laju dekomposisi serasah daun mangrove pada 20 hari pertama adalah $0,25 \mathrm{~g} /$ hari. Hal ini terjadi karena aktivitas enzim selulotik fungi (fangal cellulolic enzyme) yang paling tinggi terjadi di saat awal dekomposisi (Hodkiss dan Leung, 1986 dikutip oleh Lestarina, 2011).

Pengukuran parameter fisika-kimia perairan pada tiap stasiun dilakukan dengan masing-masing 3 kali pengulangan. Sebaran nilai parameter fisika-kimia perairan di lokasi penelitian disajikan pada Tabel 5. 
Tabel 5. Nilai parameter fisika-kimia perairan mangrove di lokasi penelitian

\begin{tabular}{lllllll}
\hline \multirow{2}{*}{ Parameter } & \multicolumn{3}{c}{ Stasiun 1 } & \multicolumn{3}{c}{ Stasiun 2 } \\
\cline { 2 - 7 } & Min & max & rata-rata & Min & max & rata-rata \\
\hline Suhu $\left({ }^{0} \mathrm{C}\right)$ & 28,4 & 30,5 & 29,3 & 26,00 & 28,20 & 27,33 \\
Salinitas $(\mathrm{psu})$ & 26,00 & 34,00 & 30,67 & 26,00 & 32,00 & 28,67 \\
pH & 6,79 & 7,88 & 7,45 & 6,84 & 7,12 & 6,99 \\
TSS $(\mathrm{g} / \mathrm{l})$ & 0,16 & 0,53 & 0,31 & 0,17 & 5,97 & 2,19 \\
\hline
\end{tabular}

Sumber : Data primer (2013)

Suhu perairan mangrove di lokasi penelitian berkisar antara 27 sampai 30,5 0C, dimana stasiun 1 (kesatu) memiliki suhu rata-rata 29,3 0C. Sedangkan pada stasiun 2 (kedua) suhu rata-ratanya mencapai $27,330 \mathrm{C}$. Suhu tertinggi terdapat pada stasiun 1 (kesatu) yaitu sebesar $30,5{ }^{\circ} \mathrm{C}$. Hal ini disebabkan oleh pengukuran suhu yang dilakukan pada siang hari. Faktor lainnya adalah letak stasiun 1 (kesatu) yang lebih terbuka sehingga intensitas cahaya yang diterima lebih tinggi.

Nilai salinitas berdasarkan hasil pengukuran berkisar antara 26--32 psu. Nilai rata-rata salinitas tertinggi terdapat pada stasiun 1 (kesatu) yakni 30,6 7 psu, hal ini disebabkan oleh stasiun 1 (kesatu) lebih dekat ke arah pantai dan mendapat pengaruh langsung air laut. Sedangkan, nilai rata-rata salinitas terendah terdapat pada stasiun 2 (kedua) yaitu 26 psu, hal ini disebabkan oleh stasiun 2 (kedua) merupakan daerah perpaduan antara air laut dan air payau. Salinitas merupakan faktor lingkungan yang sangat menentukan perkembangan hutan mangrove, terutama bagi laju pertumbuhan, daya tahan dan zonasi spesies mangrove (Aksornkoe, 1993 dikutip oleh Lestarina, 2011).

Berdasarkan hasil pengukuran diperoleh derajat keasaman $(\mathrm{pH})$ yang berbeda-beda untuk tiap substasiun. Dimana untuk stasiun 1 (kesatu) rata-rata pHnya adalah 7,45 sedangkan untuk stasiun 2 (kedua) diperoleh rata-rata pHnya adalah 6,99. Nilai pH perairan dipengaruhi oleh beberapa faktor, antara lain salinitas, aktivitas fotosintesis, aktivitas biologi, suhu kandungan oksigen dan adanya kation serta anion dalam perairan (Handayani, 2004). Reaksi tanah mempengaruhi dekomposisi bahan organik melalui pengaruhnya terhadap ketersediaan hara-hara yang dibutuhkan oleh mikrobia. Umumnya mikrobia berkembang dan aktif secara optimum pada pH (6,5--7,0) (Alexaander, 1978 dikutip oleh Hanafiah).

Kandungan Total Padatan Tersuspensi (TSS) pada stasiun 1 (kesatu) mangrove berkisar antara 0,16--0,52 g/l. Sedangkan pada stasiun 2 (kedua) kandungan TSS berkisar antara 0,17--5,96 g/l. Tingginya nilai TSS pada stasiun 2 (kedua) karena di daerah tersebut terjadi akumulasi sedimen dan bahan organik baik dari daratan maupun lautan.

Hasil pengamatan menunjukkan bahwa, faktor waktu dalam pengukuran dekomposisi serasah daun berpengaruh sangat nyata terhadap laju penghancuran serasah. Karena faktor waktu berkaitan sangat erat dengan faktor lingkungan, maka dapat dinyatakan bahwa faktor lingkungan sangat nyata pengaruhnya terhadap laju dekomposisi serasah. (Setiadi, 1989 dikutip oleh Rismunandar, 2000) menyatakan bahwa proses dekomposisi bahan organik di dalam tanah sangat dipengaruhi oleh faktor-faktor lingkungan. Peningkatan suhu tanah dapat merangsang kegiatan metabolisme flora mikro untuk mempercepat lajunya proses mineralisasi (perombakan bahan organik menjadi CO2 dengan demikian akan terdapat suatu peningkatan di dalam laju arus energi di dalam sistemnya).

\section{Kandungan Unsur Hara (C dan N)}

Kandungan unsur hara $\mathrm{C}$ dan $\mathrm{N}$ di awal pendekomposian dan di akhir pendekomposisan ditampilkan pada Gambar 4. 


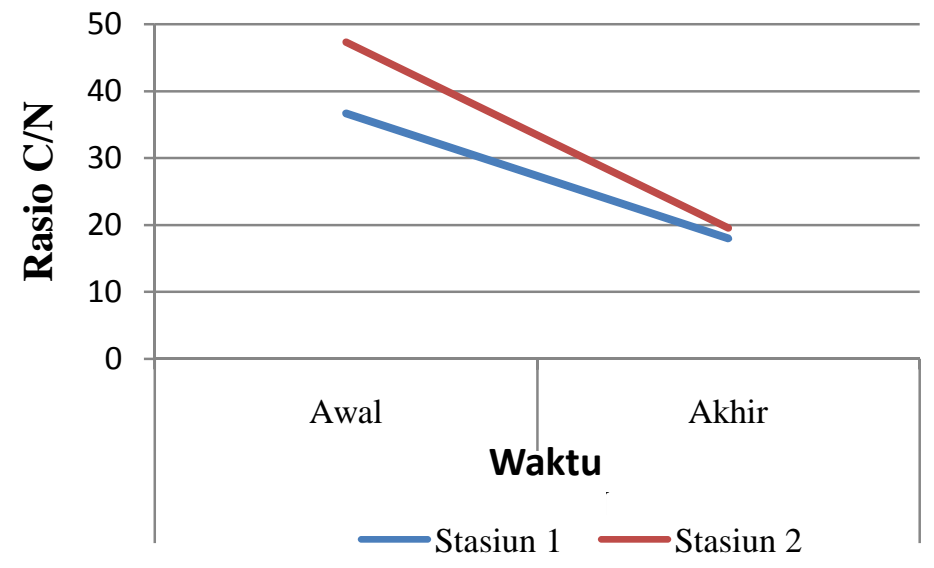

Gambar 4. Rata-rata rasio $\mathrm{C} / \mathrm{N}$ di dalam serasah.

Gambar 4 menunjukkan penurunan nilai C/N pada stasiun 1 (kesatu) dari 36,68 menjadi 18,03 atau terjadi penurunan sebesar $(50,58 \%)$. Sedangkan pada stasiun 2 (kedua) penurunan nilai $\mathrm{C} / \mathrm{N}$ dari 47,27 menjadi 19,54 atau terjadi penurunan sebesar $(58,66 \%)$. Hal ini menunjukkan bahwa stasiun 2 (kedua) mengalami penurunan $(8,08 \%)$ lebih banyak daripada stasiun 1 (kesatu) yang mengindikasikan proses dekomposisi pada stasiun 2 (kedua) berlangsung lebih cepat.

Menurut Aprianis (2011), bahwa C/N merupakan salah satu indikator untuk melihat laju dekomposisi bahan organik, karena perombakan bahan organik akan menurunkan $\mathrm{C} / \mathrm{N}$ serasah tersebut. Lebih lanjut Rindyastuti (2010), menerangkan bahwa besarnya nilai awal dan penurunannya akan berkorelasi dengan cepat dan lambatnya proses dekomposisi karena semakin rendah nilai $\mathrm{C} / \mathrm{N}$, semakin baik kandungan unsur hara $\mathrm{N}$ disebabkan oleh kemampuan bakteri nitrogen pada serasah daun untuk melakukan fiksasi nitrogen. (Alexander, 1994 dikutip oleh Wulan dkk, 2011) menyatakan rasio C:N yang tinggi (kandungan unsur $\mathrm{N}$ yang relatif rendah) akan menyebabkan proses degradasi berlangsung lebih lambat karena nitrogen akan menjadi faktor penghambat (growth-rate limiting factor).

\section{KESIMPULAN}

Produktivitas serasah hutan mangrove Padang Cermin sebesar $0,56 \mathrm{~g} / \mathrm{m}^{2} / \mathrm{hari}$, dimana organ daun memberikan kontribusi yang paling banyak (66\%) diikuti ranting dan cabang (14\%) serta bunga dan buah (20\%).

Laju dekomposisi serasah daun mangrove selama penelitian memperlihatkan bahwa stasiun 2 (dua) mengalami laju dekomposisi lebih cepat $(0,20 \mathrm{~g} / \mathrm{hr})$ dibandingkan stasiun 1 (satu) $(0.19 \mathrm{~g} / \mathrm{hr})$.

\section{DAFTAR PUSTAKA}

Asthon, E. C. et al. 1999. Breakdown of Mangrove Leaf Litter in a Managed Mangrove Forest in Peninnsular Malaysia. In Hydrobiologia 413: 77-88 p.

Aprianis, Y. 2011. Produksi dan laju dekomposisi serasah Acacia crassicarpa A.Cunn. di PT. Arara Abadi. Jurnal Tekno Hutan Tanaman. 4 (1): 41 - 47 p. 
Boonruang, P. 1984. The rate of degradation of mangrove leaves, Rhizhophora apiculata bl and Avicennia marina (forsk) vierh at Phuket Island, Western Peninsula of Thailand. In Soepadmo, E., A.N. Rao and D.J. Macintosh. 1984. Proceedings of The Asian Symposium on Mangrove Environment Research and Management. University of Malaya and UNESCO. Kuala Lumpur. 200-208 p.

Handayani,T. 2004. Laju dekomposisi sersah mangrove Rhizophora mucronata Lamk di Pulau Untung Jawa Kepulauan Seribu Jakarta. Skripsi. Institut Pertanian Bogor. Bogor.

Hanafiah, A.K. 2012. Dasar-Dasar Ilmu Tanah. Buku. PT Rajagrafindo Persada. Jakarta. $170-179 \mathrm{p}$

Lekatompessy, S. T. A. Dan Tutuhatunewa, A. 2010. Kajian konstruksi model peredam gelombang dengan menggunakan mangrove di Pesisir Lateri - Kota Ambon. Jurnal. ARIKA, 4(1).

Lestarina, M. P. 2011. Produksi dan laju dekomposisi serasah mangrove dan potensi kontribusi unsur hara di perairan mangrove Pulau Panjang Banten. Tesis. Institut Pertanian Bogor. Bogor.

Pribadi, R. 1998. The ecology of mangrove vegetation in Bintuni Bay, Irian Jaya, Indonesia. Departement of Biological and Molecular Sciences University of Stirling. Scotland. Page 53-54 p.

Sopana, A.G. 2011. Produktivitas serasah mangrove di Kawasan Wonorejo Pantai Timur Surabaya. Universitas Airlangga. Surabaya.

Sulistiyanto. 2005. Laju dekomposisi dan pelepasan hara dari serasah pada dua sub-tipe hutan rawa gambut di Kalimantan Tengah. Jurnal Manajemen Hutan Tropika XI (2) : $1-14 \mathrm{p}$.

Syamsurisal. 2011. Studi beberapa indeks komunitas makrozoobenthos di hutan mangrove Kelurahan Coppo Kabupaten Barru. Skripsi. Universitas Hassanudin. Makassar.

Wibisana, Bambang Tresna. 2004. Produksi dan laju dekomposisi serasah mangrove di wilayah pesisir Kabupaten Berau, Propinsi Kalimantan Timur. Skripsi. Institut Pertanian Bogor. Bogor.

Wulan, Praswati P.D.K., dkk. 2011. Penentuan rasio optimum C:N:P sebagai nutrisi pada proses biodegradasi benzena-toluena dan scale up kolom bioregenerator. Fakultas Teknik. Universitas Indonesia. Depok.

Zamroni, Yuliadi. 2008. Produksi Serasah Hutan Mangrove di Perairan Pantai Teluk Sepi, Lombok Barat. Jurnal BIODIVERSITAS 9 (4) : 284-287 p. 
Vol. 3 No. I, Januari 2015 (9-20)

Halaman ini sengaja dikosongkan 